\title{
SILVER LOADED CLAY AND INVESTIGATION OF THEIR ANTIMICROBIAL ACTIVITY
}

\author{
Violeta Elena Copcia ${ }^{1}$, Ion Sandu ${ }^{1}$, Nicolae Bilba $^{2}$, Simona Dunca ${ }^{3}$ \\ ${ }^{1}$ Arheoinvest Interdisciplinary Platform, Laboratory of the Scientific Investigation, \\ 22 Carol I Corp G, 700506, Iasi, Romania \\ ${ }^{2}$ Materials Chemistry Laboratory, Faculty of Chemistry, "Al. I. Cuza” University of Iasi, \\ Bvd.Carol I,no 11,700506,Romania.E-mail:vioely2003@yahoo.com \\ ${ }^{3}$ Faculty of Biology, ,Al. I. Cuza” University of Iasi, Bvd. Carol I, no 11, 700506, Romania
}

\begin{abstract}
To guarantee the microbiological quality of the water, which has been affected by the pollution of the bacterium, it is necessary to implement a tertiary drinking system in the resident houses. A possible complementary system is the utilization of clay for treatment of drinking water.
\end{abstract}

Keywords: Escherichia Coli, Staphylococcus Aureus, Clay, Silver, Silver Nanoparticles

\section{Introduction}

Clay can be used for dispersion of $\mathrm{Ag}^{+}$and $\mathrm{Ag}^{0}$ nanoparticles activity having permanent removal of coliforrm bacteria normally found in natural water. Clinoptilolite resulting with antibacterial effect of $\mathrm{Ag}^{+}$and $\mathrm{Ag}^{0}$ nanoparticles/ clay was made from two bacteria: Escherichia coli ATCC 25922 and Staphylococcus aureus ATCC 25923.

In this study, local natural clays from Răzoare areas have been investigated. Samples were used in the raw form (polycationic form) as well as in the Na-exchanged form.

\section{Experimental}

The Na-forms of the natural clays from Răzoare were prepared by treating the clay polycationic forms with $\mathrm{NaCl}$ $1 \mathrm{M}$ in a solid/liquid ratio of $1: 10$, at room temperature, under magnetic stirring for 12 hours, followed by centrifugation, water washing and air drying at $80^{\circ} \mathrm{C}$ for 5 hours.

The samples of clay in homoionic form of $\mathrm{Na}^{+}\left(\mathrm{R} 1-\mathrm{Na}^{+}\right)$were suspended in $0.1 \mathrm{M} \mathrm{AgNO}_{3}$ solution at room temperature for $24 \mathrm{~h}$ in the dark (threefold with fresh solution), adjusting the solution to $\mathrm{pH} 5.0$, with intermittent shaking to obtain the silver - loaded clay named R1- $\mathrm{Ag}^{+}$. The resulting solids were separated by filtration, washed with deionized water several times and dried overnight at room temperature. If the $\mathrm{pH}$ of exchange is greater than 7.5-8, the samples become dark because $\mathrm{Ag}^{+}$in the zeolite turned to $\mathrm{Ag}^{0}$. Samples results were analyzed by FTIR and SEM. (Fig. 1).

After preparing inoculum and culture media, clay species were put in contact with the surface agarizat environment. After 24 hours of incubation was followed by inhibition of bacterial growth phenomenon by the appearance of lysis zones around clinoptilolite with $\mathrm{Ag}^{+}$and $\mathrm{Ag}^{0}$ nanoparticles clay (Fig. 2 and 3).

\section{Results and discussion}

We incorporate $\mathrm{Ag}^{+}$in a clay carrier. The ion exchange of $\mathrm{Ag}^{+}$with other positive ions (often sodium) from the moisture in the environment, will give a release of silver "on demand". The structural location of $\mathrm{Na}^{+}$cations, the channel dimensions and the hydrated ionic radii of $\mathrm{Na}^{+}(3.58 \AA)$ are involved in the easily exchange with hydrated $\mathrm{Ag}^{-}$ ion (3.43 $\AA$ ) [1-4] The $\mathrm{Na}^{+}$cations are preferable for $\mathrm{Ag}^{+}$instead of $\mathrm{Ca}^{2+}, \mathrm{K}^{+}$and $\mathrm{Mg}^{2+}$ found in the natural clay.

FTIR spectra of the samples and silver exchanged, $\mathrm{R} 1-\mathrm{Na}^{+}$and $\mathrm{R} 1-\mathrm{Ag}^{+}$, were investigated between 600 and 4000 region (fig.1). The vibration band assignments of the samples are summarized in table 1.

The SEM micrographs in fig.1 confirmed the phase purity of the crystal morphology. Also, the SEM micrographs showed that the particles were closely similar in size and appearance, which suggests that the loading of silver ions into framework seems to have little or no effect on the size of the zeolite.

After 24 hours of incubation was followed by inhibition of bacterial growth phenomenon by the appearance of lysis zones around particles of $\mathrm{Ag}^{+}$clinoptilolite.(Fig. 2 and 3) 


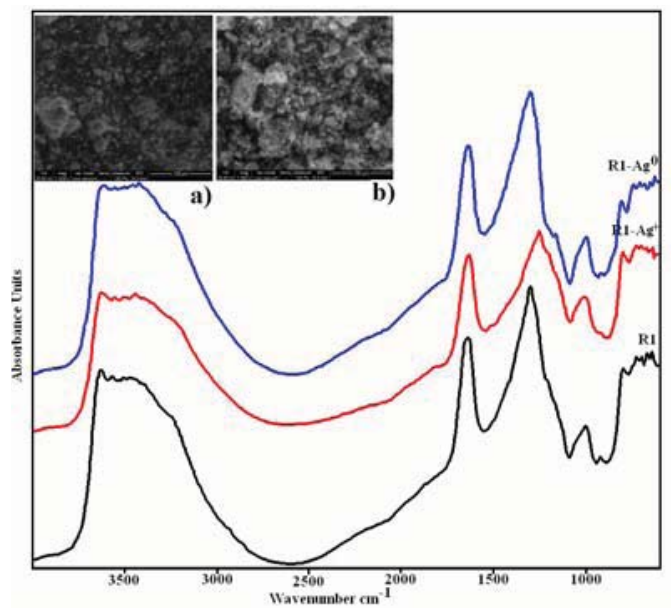

Fig. 1. FTIR spectrum of sample R1, R1-Ag and R1-Ag and SEM micrographs of R1-Na ${ }^{+}$(a) $\mathrm{R} 1-\mathrm{Ag}^{+}$(b)

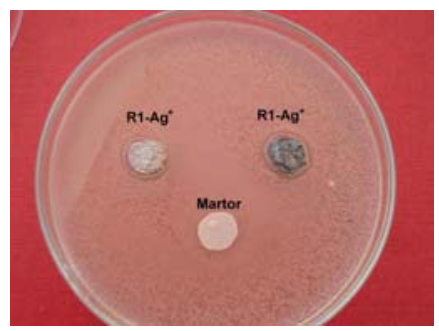

Fig.2. Antibacterial test results using Escherichia coli ATCC $25922 \mathrm{P}_{1}-\mathrm{P}_{\mathrm{b}}$ treated with $\mathrm{AgNO}_{3}, \mathrm{P}_{2}-\mathrm{P}_{\mathrm{a}}$ treated with $\mathrm{AgNO}_{3}$,
Table 1

Assignments of vibration bands of the initial and $\mathrm{Ag}^{+} / \mathrm{Ag}^{0}$ exchanged forms of the clay samples [4-7]

\begin{tabular}{|l|c|c|c|}
\hline \multirow{2}{*}{\multicolumn{1}{|c|}{ Vibration modes }} & \multicolumn{3}{|c|}{ Frequency (1/cm) } \\
\cline { 2 - 4 } & $\mathrm{R} 1$ & $\mathrm{RR} 1-\mathrm{Ag}^{+}$ & $\mathrm{R} 1-\mathrm{Ag}^{0}$ \\
\hline External double ring & 719.15 & 698.55 & 706.43 \\
\hline External asymmetric stretch & 792.94 & 795.91 & 802.53 \\
\hline External symmetric stretch & 996.95 & 1008.91 & 995.46 \\
\hline Internal asymmetric stretch & 1297.25 & 1248.10 & 1299.49 \\
\hline OH bending & 1633.27 & 1627.94 & 1632.05 \\
\hline H-bonded OH stretching & 3432.81 & 3432.17 & 3423.64 \\
\hline Isolated OH stretching & 3616.77 & 3618.70 & 3611.49 \\
\hline
\end{tabular}

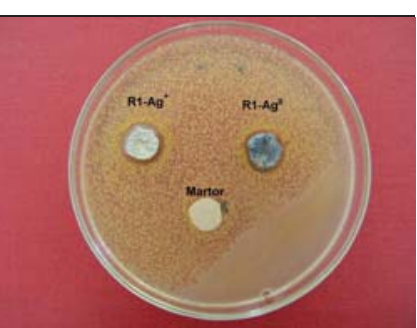

Fig.3. Antibacterial test results using Staphylococcus aureus ATCC $25923\left(\mathrm{P}_{1}-\mathrm{P}_{\mathrm{b}}\right.$ treated with $\mathrm{AgNO}_{3}, \mathrm{P}_{2}$ $\mathrm{P}_{\mathrm{a}}$ treated with $\mathrm{AgNO}_{3}$ ),

\section{Conclusions}

$\mathrm{Ag}^{+}$-clay was tested for their antimicrobial activity against $E$. coli and $S$. aureus. The bactericidal activity depended on the permeability and penetration rate against the bacteria cell wall.

Results showed that the silver highly dispersed on clay structure exhibited a good inhibition effect on the growth of Escherichia coli ATCC 25922 and Staphylococcus aureus ATCC 25923. The inhibitory effects of silver were dependent on amount of $\mathrm{Ag}^{+}$-clay and $\mathrm{Ag}^{0}$-clay added.

The $\mathrm{R} 1-\mathrm{Ag}^{0}$ sample is more prolific than $\mathrm{R} 1-\mathrm{Ag}^{+}$sample. Thus $\mathrm{R} 1-\mathrm{Ag}^{0}$ sample is a good candidate with potential antibacterial applications.

\section{Acknowledgments}

The authors are grateful the financial support of POSDRU/89/1.5/S/63663 Projects

\section{References:}

[1]. Inoue Y.; Hoshino M.; Takahashi H.; Noguchi T.; Murata T.; Kanzaki Y.; Hamashima H.; Sasatsu M., J. Inorg. Biochem 2002, 92, 37-42.

[2]. Song H.Y, Ko K.K, Oh I.H, Lee B.T, European Cells and Materials 2006, 11, 58.

[3]. Copcia V.E.; Luchian C.E.; Dunca S.; Bilba N.; Hristodor C.M. Journal of Materials Science 2011, 46, 71217128.

[4]. Rivera-Garza M. ; Olguin M.T. ;M Garcia-Sosa I. ; Alcantara D. ; Rodriguez-Fuentes G. Micropor. Mesopor. Mater. 2000, 39, 431-444.

[5]. Woods R.M.; Gunter M.E. Am Mineral 2001, 86, 424-430.

[6]. Wilson M.J. Clay Mineralogy: Spectroscopic and Chemical Determinative Methods. (Chapman\& Hall, New York) $1994,52-55$

[7]. Tanaka H.; Yamasaki N.; Muratani M.; Hino R. Material Research Bulletin 2003, 38, 713-722. 